\title{
Evaluation of the medication reconciliation service in a private hospital in Fortaleza-CE: Quality indicators
}

\author{
Flavio Rodrigues FILHO ${ }^{1}$ (D), Paulo Yuri FIRMINO ${ }^{1}$ (D), Natália Martins FREIRE ${ }^{\text {(D) }}$ \\ ${ }^{1}$ Centro Universitário Unifametro, Fortaleza, Brasil; ${ }^{2}$ Hospital União das Clínicas (UNICLINIC), Fortaleza, Brasil \\ Corresponding author: Filho FRL , frodrigues996@gmail.com \\ Submitted: 26-12-2020 Resubmitted: 14-03-2021 Accepted: 14-03-2021 \\ Peer review: blind reviewers
}

\begin{abstract}
Objective: Analyze the registered results of this drug conciliation service on hospital admission to a private hospital in Fortaleza-CE, based on quality indicators, such as the reconciliation rate and operations performed. Methods: A cross-sectional retrospective study in which anamnesis data was collected in the medication reconciliation service of a private hospital in Fortaleza-CE, and with the registration of patients, data such as name, responsible physician, age, pharmaceutical intervention carried out, highlighting its impact on the quality of service for increasing patient safety, and with these records an analysis of the indicators was made in relation to the doctors' acceptance and the monitoring in relation to the validation of the prescribed drugs and classes, in July to December 2018. 833 patients (divided into clinical and surgical ones) with more than 48 hours of hospitalization were included, in whom medication reconciliation was performed at the time of admission to the 7 hospitalization stations present at the hospital. Results: 119 patients were reconciled in the study and that among the patients 294 interventions were performed, of which 228 were accepted, showing high performance in terms of acceptance, efficiency and quality of service. In addition, there was a result of high acceptance in the month following the implantation, in August, with $29.4 \%$, falling in October to 9.3\%, suggesting that the service improved the prescription culture, requiring fewer interventions and promoting a increasing patient safety. The main intervention was the addition of medications, evidencing the communication to the medical team of the existence of comorbidities that were not being treated. Conclusion: The medication reconciliation in the hospital environment identified the need to add medications, as the most common intervention. In addition to the need to communicate patients' comorbidities to the medical team, because of this intervention presenting itself as a great tool with the participation of the pharmacist in the clinical care of the patient in order to promote patient safety, increasing the quality of the prescription at the time of hospitalization.
\end{abstract}

Keywords: drug therapy; pharmaceutical services; pharmacist; medication reconciliation; pharmacy service, hospital; patient safety.

\section{Avaliação de um serviço de reconciliação medicamentosa em um hospital privado de Fortaleza-CE: indicadores de qualidade}

\section{Resumo}

Objetivo: Analisar os resultados registrados desse serviço de reconciliação de medicamentos na admissão hospitalar de um hospital privado de Fortaleza-CE, a partir de indicadores de qualidade, como a taxa de conciliação e intervenções realizadas. Métodos: Estudo seccional retrospectivo no qual foram coletados dados de anamnese realizada no serviço de reconciliação de medicamentos de um hospital privado de Fortaleza-CE, e com o registro dos pacientes, verificou-se dados, como nome, médico responsável, idade, intervenção farmacêutica realizada, ressaltando seu impacto na qualidade do serviço para o aumento da segurança do paciente e com esses registros foi feita uma análise dos indicadores em relação a aceitação dos médicos e do acompanhamento em relação a validação dos medicamentos e classes prescritas, no período de julho a dezembro de 2018. Foram incluídos 833 pacientes (divididos em de origem clínica e cirúrgica) com mais de 48 horas de internação, nos quais foi realizada reconciliação de medicamentos no momento da admissão nas 7 estações de internação presentes no hospital. Resultados: O estudo mostrou que 119 pacientes foram conciliados no estudo e que entre esses pacientes foram realizadas 294 intervenções, das quais 228 foram aceitas, apresentando alto desempenho em termos de aceitação, eficiência e qualidade do serviço. Além disso, houve um resultado de alta aceitação no mês seguinte à implantação, em agosto, com $29,4 \%$, caindo em outubro para $9,3 \%$, sugerindo que o serviço melhorou a cultura de prescrição, necessitando de menos intervenções e promovendo um aumentando da segurança do paciente. A principal intervenção foi a adição de medicamentos, evidenciando a comunicação à equipe médica da existência de comorbidades que não estavam sendo tratadas. Conclusão: a reconciliação de medicamentos no ambiente hospitalar identificou a necessidade de adição de medicamentos, como a intervenção mais comum, além da necessidade de comunicar as comorbidades dos pacientes à equipe médica, visto que esta intervenção se apresenta como ótima ferramenta com a participação do farmacêutico no cuidado clínico do paciente a fim de promover a segurança do paciente, aumentando a qualidade da prescrição no momento da internação.

Palavras-chave: tratamento farmacológico; serviços farmacêuticos; farmacêutico; reconciliação de medicamentos; serviço de farmácia hospitalar; segurança do paciente. 


\section{Introduction}

Patient safety is defined as the act of avoiding, preventing or improving adverse effects or injuries arising from medical and hospital care; thus, it is a public health issue, considering that the risks and events that can cause harm to the patients are present in several different environments, mainly the hospital setting. The issue in relation to ensuring effective and safe assistance becomes increasingly difficult, either due to the negligence of the health professionals or even to the lack of information by the users of the care service. ${ }^{1}$ Some data indicate that 1 out of 10 patients in developed countries is harmed when receiving hospital care. ${ }^{2}$

One of the services routinely provided by the health professionals in the hospital environment is medication reconciliation, which consists in the process of obtaining a complete, accurate and up-todate list of the medications used by each patient, including related data (name of the medication, dose, frequency of use, route of administration), comparing them with medical prescriptions made at different times during hospitalization, such as admission, transfer, appointments and discharge. ${ }^{3}$ An evaluation by researchers on a medication reconciliation program identified that there was a $78 \%$ reduction in the risk of death for individuals in the group in which the interventions were conducted, compared to the control group, emphasizing the importance of this practice in a hospital environment. ${ }^{1}$

For a good execution of the processes, it is necessary to measure the quality of a service and. for the health area, this means "achieving the greatest benefits, with the lowest possible risks for the patients, using some resource". Thus, the evaluation of the medication reconciliation service becomes important because, from the quality indicators, it is possible to monitor and evaluate management, production and quality within the service provided, in addition to offering a direction to solve problems and also bringing new proposals for the reality of each environment, made possible by the information recorded, which generates quality indicators that can guide the service and prompt improvements for each culture in which it is employed. ${ }^{4}$ In view of the above, this study aimed to analyze the performance of this pharmaceutical service at hospitalization in a private hospital in Fortaleza-CE, based on quality indicators recorded in a spreadsheet.

\section{Methods}

This was a retrospective cross-sectional study as it evaluated data collected from medication reconciliation at a private hospital with 16 medical specialties (including digestive tract surgery, general surgery, general practice, sports medicine, urology, bariatric surgery, plastic surgery, endoscopy, neurosurgery, spine surgery, otorhinolaryngology and infectious diseases, as well as a reference in traumatology and orthopedics), located in the city of FortalezaCE; the study was conducted between July and December 2018 and covered all clinical and surgical patients with more than 48 hours of hospitalization, in which medication reconciliation was performed at the time of admission to the 7 inpatient units present at the hospital, where clinical and surgical patients were randomly assigned.

The work was also descriptive, as it evaluated the service of medication reconciliation and use by patients after hospitalization, as well as experimental and documentary, as it used the data collected from quality indicators, with a quantitative approach.

This study included all clinical patients hospitalized, as well as surgical patients with more than 48 hours of hospitalization, with medication reconciliation performed by pharmacy students and pharmacists working in the clinic pharmacy service of a secondary hospital. This service operates in the hospital from Mondays to Fridays, except holidays, only for inpatient units. Patients who were discharged before medication reconciliation were excluded from the study, as well as those who did not use medication prior to their hospitalization.

The data were collected from anamneses performed in the medication reconciliation service at the available times of the pharmacy students and pharmacists from Mondays to Fridays; patients who were hospitalized on days that had no medication reconciliation were relocated to the later next date; the medications, in particular, were listed based on the patient's report and thus used to compare with the prescription at that time. The divergences were registered and exposed in the medical record in a pharmaceutical intervention form, demonstrating the observed discrepancy and providing space for justifications, subjected to evaluation in 48 hours. The following were recorded as data for the service: patient's name, gender, age, bed, number of medications in need of reconciliation, hospitalization unit, responsible clinical or surgical physician, corresponding medication class, intervention (divided into 6 classes: adjustment in administration route, dose adjustment, adjustment in use frequency, medication substitution, and whether the medication is not prescribed, and others). It was also reported whether the intervention was accepted by the physician, thus assessing the professional's adherence to the service, to check the quality of the service, and justifications were requested for why the intervention could not be performed, in order to verify the real impacts for patient safety, thus being the main variables studied.

The data were analyzed according to the information collected in the medication reconciliation service, compiled in a spreadsheet, subjected to discussions regarding the pre-existing literature, and allocated based on the creation of graphs, tables, measures of central tendency for numerical variables, frequency and percentage for the categorical ones, generating quality indicators such as level of acceptance of the interventions, main classes of medications commonly reconciled, and frequency during the months, using Microsoft Excel 2013. This study was approved by the Research Ethics Committee (Comitê de Ética em Pesquisa, CEP) of the Fametro University Center, under opinion No.: $3,189,412$.

\section{Results}

Data referring to the medication reconciliation service from July to December 2018 were analyzed, with patients in a secondary unit from the city of Fortaleza, state of Ceará, presenting a total of 823 patients who attended the reconciliation interview. Of these, 461 were female (56.0\%) and 362 were male (44.0\%). Medication reconciliation was required in 119 (14.2\%) patients: 71 women (59.7\%) and 48 men (40.3\%).

The patients were also divided into patients hospitalized for surgery, called surgical patients, patients hospitalized for clinical interventions and surgical patients who later also needed clinical 
follow-up, who were also considered clinical patients. A total of 12 surgical patients (10\%) and 107 clinical patients (90\%) were reconciled.

The age of the reconciled patients varied from 18 to 99 years old. The mean age of the patients was 67.92 (with a standard deviation of 16.05) and the age groups with the highest incidence of reconciliation in decreasing order were as follows: 61 to 70 years old, with 34 patients (28.6\%); 81 to 90 years old, with 27 patients (22.7\%); 71 to 80 years old, with 23 patients (17.6\%); 51 to 60 years old, with 18 patients (15.1\%); 91 to 99 years old, with 5 patients (4.2\%); and the age groups of 31 to 40 years old and from 41 to 50 years old with 4 patients (3.4\%) each.

Among the months during which the reconciliations were conducted, the one that presented the highest rate of reconciled patients was August, with $29.4 \%$ of the total sample. The month with the lowest rate was October, with $9.3 \%$ of the total sample (Table 1).

Table 1. Number of patients and medications that participated in the medication reconciliation process of a secondary level hospital, stratified by month of the year 2018 (Fortaleza, Ceará; $n=119$ ).

\begin{tabular}{|c|c|c|c|c|}
\hline \multirow{2}{*}{ Information } & \multirow{2}{*}{$\begin{array}{l}\text { Total patients } \\
\mathrm{N}=823\end{array}$} & \multirow{2}{*}{$\begin{array}{l}\text { Patients reconciled } \\
\mathrm{N}=119\end{array}$} & \multicolumn{2}{|c|}{ Medications with interventions } \\
\hline & & & Accepted $\mathrm{N}=\mathbf{2 2 8}$ & Not accepted $\mathrm{N}=66$ \\
\hline \multicolumn{5}{|l|}{ Sociodemographic } \\
\hline Female gender ${ }^{1} \mathrm{n}(\%)$ & $461(56.0)$ & $71(59.7)$ & $120(52.6)$ & $36(54.5)$ \\
\hline Age (years old) Mean (SD) & $67.9(16.1)$ & $69.91(16.12)$ & $69.91(16.1)$ & $45.0(16.0)$ \\
\hline \multicolumn{5}{|l|}{ Origin } \\
\hline Surgical clinic & $53(6.44)$ & $12(10)$ & $47(20.6)$ & $45(68.1)$ \\
\hline Medical clinic & $770(93.56)$ & $107(90)$ & $181(79.4)$ & $21(31.9)$ \\
\hline \multicolumn{5}{|l|}{ Period } \\
\hline July & $167(20.3)$ & $19(16.0)$ & $40(17.5)$ & $12(18.2)$ \\
\hline August & $211(25.6)$ & $35(29.4)$ & $77(33.8)$ & $17(25.8)$ \\
\hline September & $105(12.8)$ & $18(15.1)$ & $34(14.9)$ & $9(13.6)$ \\
\hline October & $126(15.3)$ & $11(9.3)$ & $16(7.0)$ & $6(9.0)$ \\
\hline November & 119 (14.5) & $19(16.0)$ & 34 (14.9) & $12(18.1)$ \\
\hline December & 95 (11.5) & $17(14.2)$ & $27(11.8)$ & $10(15.1)$ \\
\hline Medications & \multicolumn{2}{|c|}{ Total medications with interventions $\mathrm{N}=294$} & Accepted N=228 & Not accepted $\mathbf{N}=66$ \\
\hline Alkalizing & \multicolumn{2}{|c|}{$2(0.7)$} & $2(0.9)$ & - \\
\hline Analgesics & \multicolumn{2}{|l|}{$1(0.3)$} & $1(0.4)$ & - \\
\hline Antiacids & \multicolumn{2}{|l|}{$4(6.0)$} & $3(1.3)$ & $1(1.5)$ \\
\hline Anxiolytics & \multicolumn{2}{|l|}{$9(3.6)$} & $9(3.9)$ & - \\
\hline Antiplatelets & \multicolumn{2}{|l|}{$21(7.1)$} & $14(6.1)$ & $7(10.6)$ \\
\hline Antiarrhythmics & \multicolumn{2}{|l|}{$14(4.8)$} & $11(4.8)$ & $3(4.5)$ \\
\hline Antiasthmatics & \multicolumn{2}{|l|}{$2(0.7)$} & $2(0.9)$ & - \\
\hline Anticonvulsants & \multicolumn{2}{|l|}{$10(3.4)$} & $10(4.4)$ & - \\
\hline Antidepressants & \multicolumn{2}{|l|}{$13(4.4)$} & $13(5.7)$ & $3(4.5)$ \\
\hline Antidiabetics & \multicolumn{2}{|l|}{$44(15.0)$} & $23(10.1)$ & $21(31.8)$ \\
\hline Antigouts & \multicolumn{2}{|l|}{$2(0.7)$} & $2(0.9)$ & - \\
\hline Antihypertensives & \multicolumn{2}{|l|}{$55(18.7)$} & $48(21.1)$ & 7 (10.6) \\
\hline Anti-inflammatories & \multicolumn{2}{|l|}{$1(0.3)$} & $1(0.4)$ & - \\
\hline Anti-ischemics & \multicolumn{2}{|l|}{$2(0.7)$} & $2(0.9)$ & - \\
\hline Antilipemics & $33(11.2)$ & & $22(9.6)$ & $11(16.7)$ \\
\hline Antimetabolics & $2(0.7)$ & & $2(0.9)$ & - \\
\hline Antimicrobials & $1(0.3)$ & & $1(0.4)$ & - \\
\hline Antineoplastics & $2(0.7)$ & & $2(0.9)$ & - \\
\hline Antiparkisonians & $2(0.7)$ & & $1(0.4)$ & $1(1.5)$ \\
\hline Antipsychotics & $12(4.0)$ & & $9(3.9)$ & $3(4.5)$ \\
\hline Antiretrovirals & $1(0.3)$ & & $1(0.4)$ & - \\
\hline Bronchodilators & $2(0.7)$ & & $1(0.4)$ & $1(1.5)$ \\
\hline Dilators & $2(0.7)$ & & $2(0.9)$ & - \\
\hline Expectorants & $1(0.3)$ & & $1(0.4)$ & $0(0)$ \\
\hline Hypnotics & $7(2.4)$ & & $6(2.6)$ & $1(1.5)$ \\
\hline Thyroid Hormone & $8(2.7)$ & & $7(3.1)$ & $1(1.5)$ \\
\hline Laxatives & $1(0.3)$ & & $1(0.4)$ & - \\
\hline Neuroprotectors & $1(0.3)$ & & $1(0.4)$ & - \\
\hline Gastric protectors & $4(1.4)$ & & $3(1.3)$ & $1(1.5)$ \\
\hline Electrolyte replenishers & $10(3.4)$ & & $8(3.5)$ & $2(3.0)$ \\
\hline Treatment of dementia & $6(2.0)$ & & $6(2.6)$ & - \\
\hline Vasodilators & $8(2.7)$ & & $5(2.2)$ & $3(4.5)$ \\
\hline Vitamines & $8(2.7)$ & & $7(3.1)$ & $1(1.5)$ \\
\hline
\end{tabular}

${ }^{1}$ Dichotomous variable in which the results of only one of the alternatives were presented. 
The total number of reconciled and accepted medications was 228 . August presented the highest number, with 77 (34\%) reconciled medications, and the lowest number was in October, with 11 medications (9.3\%). The months of July, September, November and December remained in a marginal position, between 25 and 40 reconciled medications. The result of the number of medications reconciled per month is in agreement with the number of patients who needed interventions, thus linking to the previous data.

The types of interventions related to medication reconciliation were divided as follows: 1 - Dose adjustment, 2 - Medication substitution, 3 - Adjustment in use frequency, 4 - Adjustment in administration route, 5 -Adjustment in schedule, and 6 -Addition of medications. Only interventions 1, 3 and 6 obtained results, with most of the interventions being number 6 with a total of 211 (92.54\%), followed by interventions number 3 with a total of 11 (4.82\%) and, finally, interventions number 1 with 6 (2.63\%).

Overall, there was reconciliation of 36 therapeutic classes and the classes that presented, in the study period, a number greater than 10 reconciled drugs per class were the following: antiarrhythmic, anticonvulsant, antidepressant, antidiabetic, antihypertensive and antilipemic medications (Table 1).

Three antiarrhythmic medications needed to be reconciled: atenolol, bisoprolol and carvedilol. Of the reconciled patients, $7(5.88 \%)$ needed interventions related to atenolol, followed by bisoprolol and carvedilol, where $2(1.6 \%)$ patients required interventions. Of the medications in the anticonvulsant class, the one that most needed interventions was Pregabalin, with 4 (3.36\%) patients. Other medications required reconciliation in the class, such as Phenytoin, with $3(2.52 \%)$ patients; Sodium Valproate, with $2(1.68 \%)$ patients; and Oxcarbazepine, with 1 (0.84\%) patient.

Of the antidepressant medications, the ones that most needed interventions with medication reconciliation were Duloxetine, Escitalopram and Fluorextine, in $3(2.52 \%)$ patients. The other antidepressants that needed interventions were the following: Citalopram, Mirtazapine, Olanzapine and Trazodone, with 1 (0.84\%) patient each.

Losartan was the medication that presented the largest number of interventions, conducted in 19 (15.96\%) of the reconciled patients. Other medications that required interventions in this class include Hydrochlorothiazide, with 8 (6.72\%) patients; Metoprolol, Furosemide, Doxasozine, Chlortalidone, Carvedilol and Captopril, with 2 (1.68\%) patients; and, finally, $1(0.84 \%)$ patient needed intervention using Valsartan + Hydrochlorothiazide, Ramipril + Anlodipine, Nitrendipine, Nimodiline, Enalapril, Candesartan + Hydrochlorothiazide, Atenolol and Amlodipine.

Of the medications in the antidiabetic class, the one that most needed interventions was Metformin, being required in 9 (7.56\%) of the patients under reconciliation. Other medications of the class were also subjected to interventions, such as the following: Glicazide, with 5 (4.20\%) patients; Glibenclamide, with 4 (3.36\%) patients; NPH Insulin, with $3(2.52 \%)$ patients; and the ones where $1(0.84 \%)$ patient needed intervention were Arcabose, Linagliptin, and Sitagliptin + Metformin.

Of the antilipemic medications, the one that most needed interventions was Simvastatin, with 13 (10.92\%) reconciled patients; in addition to others in this therapeutic class, such as Ciprofibrate, with 5 (4.20\%) patients; Clopidogrel, with 2 (1.68\%) patients; and Atorvastatin and Rosuvastatin, with 1 (0.84\%) patient each.
The acceptance level of the interventions was considered high $(77.5 \%)$ and is in accordance with other studies that verified the acceptance level with the following results: Institute for Healthcare Improvement: $88.7 \%$, Frizon et. al: $387 \%$ and Gleason et. $a l:{ }^{9} 71.1 \%$, maintaining a high margin; and others with low acceptance level, such as Domingos ${ }^{5}$ with $31.5 \%$, Lessard ${ }^{10}$ with $40 \%$, and Vira ${ }^{11}$ with $46 \%$.

\section{Discussion}

The number of patients who needed medication reconciliation presented a low coverage result in relation to the number of patients interviewed. This is possible due to the high turnover of the hospital, considering that, for the most part, for being a secondary unit of reference in trauma and orthopedics, hospitalizations end up being brief, as confirmed by the smaller number of reconciled surgical patients.

Another preponderant factor is that the reconciliation service performed by the hospital's pharmacy unit only works on weekdays and during business hours; therefore, many patients had been discharged or, due to the amount of time, another professional had already carried out the medication reconciliation process, considering that it is not an exclusive activity of the pharmacist.

The age group with the largest number was that of aged patients, according to another study ${ }^{5}$ that evidences higher incidence in this age group, as well as predominance of females, due to the larger number of individuals belonging to this gender in these age groups, with a greater relationship with health care among women ${ }^{5}$.

Medication reconciliation was initiated in July and, with this, several educational measures were directed to the nursing and medical team, with the intention that they would adhere to the flow proposed by the pharmacy unit, so as to stipulate one more measure in order to ensure patient safety. They were based on a study ${ }^{6}$ that highlights the need to follow a series of steps for the implementation, as there is a demand for awareness raising in the professionals and, above all, the need to have a concrete and well-defined structure to reduce errors in the reconciliationrelated procedures as well. ${ }^{6}$

August appears as the month that presented the largest number of reconciled patients; this can be explained mainly by the service intensification in that month. From the data, it is verified that many patients were not offered medication reconciliation due to failures that could occur in any of the hospitalization stages, as well as to omission by the nursing and medical team. The following months show a drop in the need for reconciliation and a similar margin, thus showing that the team became more attentive to carry out the reconciliation.

The largest number of interventions corresponded to the addition of medications, thus highlighting the failures related to communication about the medications that the patient was using prior to hospitalization. As the largest number of interventions, other studies ${ }^{3-7}$ also pointed out the need to add or verify the omission of medications by the team.

Many times, the patients were not monitored with glycemic tests as the fact that they were diabetics was not included in the chart, or that they were using some medication for this purpose. This omission can compromise the clinical conduct with hospitalized patients in several ways and it could be 
avoided if the entire multidisciplinary team was searching more actively for the medication reconciliation service. As well as the other interventions, given that their causes are due to failed communication and transcription errors, among others. ${ }^{29-31}$

Considering the medications with the largest numbers in the interventions, the ones that stand out are mainly those for the treatment of Diabetes Mellitus, Systemic Arterial Hypertension, Dyslipidemias and Depression. Some studies ${ }^{3-5}$ also emphasize that the main demand in medication reconciliation is for the treatment of these comorbidities.

In relation to the discrepancies found, they were registered in medical records to investigate their clinical justification. When there was none, the pharmaceutical intervention was then carried out so that the physician could verify it and, after 24 hours, change the prescription. The values found in this study are mostly in agreement with most of the other studies carried out; however, the implementation process guarantees quite divergent results compared to other studies that evaluate service continuity, considering that it is a process that demands reorganization of the team and encouragement of multidisciplinary communication, in addition to time to sensitize all employees with respect to the flow and ensure that there is adherence to that flow. ${ }^{17-20}$

The main interventions not accepted in the study were those of antiplatelet, antidiabetic and antilipemic medications. Antiplatelet medications were mostly used preventively for thrombotic events, but several clinical and surgical physicians justified their absence due to the presence of patients in need of surgical interventions and, therefore, non-prescription of this class in order to prevent bleeding and hemorrhages. Oral antidiabetics were often justified as not prescribed because they generally report a risk of metabolic acidosis. In these cases, the patient's condition was evaluated and then a discussion was held to find the best conduct for the patient, such as, for example, prescription of insulin therapy with glycaemia check during the day. As well as with the antilipemic medications, since they are mostly statins, which were often justified as not included in the prescription due to the prevention of muscle harms, especially in bedridden patients. ${ }^{15-20}$

Antihypertensive medications were the ones with the highest number of drugs in a class in need of interventions, generating a total of 17 medications. This class is also involved in preventing cardiovascular events, in addition to ensuring adequate treatment with the same therapy that was done before hospitalization, thus not desensitizing the organism to the effect of the substance that was previously used. ${ }^{15}$

Regarding the study limitations, the fact that most of the hospitalizations are surgical procedures for orthopedics or trauma delimits a very specific and less dynamic flow, reducing their stay in the hospital, considering that patients subjected to these procedures are generally discharged in less than 48 hours, which would require interventions at the time of the patient's hospitalization, which becomes difficult in view of the time taken for the reconciliation of medications in the period. .1-23;32 $^{2}$

Pharmaceutical professionals working in this multidisciplinary communication of the medication reconciliation flow add even more advantages due to their technical-scientific knowledge, in addition to an in-depth dimension of the hospital's standardization, thus favoring a better intervention and also guidance for the entire team. ${ }^{28}$
The work proved to be important to evidence that the implementation of this service brings several potentially positive factors with respect to patient safety, in addition to promoting clinical discussions that guarantee a better treatment for the patient during hospitalization, mainly to avoid lack of knowledge of morbidities during their hospital stay and to seek the best therapy alternative for the patients in view of their current condition. ${ }^{25-26}$

\section{Conclusion}

The results obtained show the importance of medication reconciliation within the hospital environment, representing a great tool with the participation of the pharmacist in the clinical care of the patients. Based on the fact that the omission of medications during hospitalization is the main reason for reconciliation, this study highlights the need to always try to communicate effectively with the patients, seeking correct and complete information, as occurred with the intensification of the reconciliation service, in which there were several initial interventions and later there was stability and a reduction in the number of interventions, thus showing an improvement in the prescriptions and greater evaluation of the professionals involved in order to avoid interventions. The predominant comorbidities are mainly a reflection of the hospital's patients, for them belonging to older age groups, thus having a propensity to home polymedication to treat various diseases continuously, avoiding complications due to these untreated comorbidities that could increase the patient's hospitalization time.

\section{Funding sources}

The research did not receive funding for its conduction.

\section{Collaborators}

Filho, FR: Conception and design or data analysis and interpretation, and writing of the article or relevant critical review of the intellectual content. Firmino, PYM: Conception and design or data analysis and interpretation. Freire, NM: Conception and design or data analysis and interpretation.

\section{Acknowledgments}

To our friends and professors from Unifametro who collaborated with the research, and to Natália Martins Freire (the hospital's coordinator), who helped in the data processes.

\section{Declaration of conflict of interests}

The authors declare that there are no conflicts of interest in relation to this article.

\section{References}

1. Ferraz CLAS. A Importância da Reconciliação Medicamentosa na Internação Hospitalar. Revista On-Line IPOG Especialize. 2015;1:1-14. 
2. Silva ACA, Da Silva JF, Santos LRO, et al. A segurança do paciente em âmbito hospitalar: revisão integrativa da literatura. Cogitare Enferm. 2016;21(5):01-09.

3. Frizon F, Dos Santos AH, Caldeira LF, et al. Reconciliação de medicamentos em hospital universitário. Rev enferm UERJ. 2014;22(4):454-60.

4. Lombardi NF, Mendes AEM, Lucchetta RC, et al. Análise das discrepâncias encontradas durante a conciliação medicamentosa na admissão de pacientes em unidades de cardiologia: um estudo descritivo. Rev. Latino-Am. Enfermagem. 2016;24:27-60.

5. Domingos SCF. Discrepâncias na medicação e reconciliação terapêutica em doentes internados: uma avaliação descritiva [Dissertação de mestrado]. Universidade de Lisboa, Lisboa, 2013.

6. Alvim BA. Importância da implantação e desenvolvimento da reconciliação medicamentosa em hospitais [Monografia de TCC]. Centro Universitário Luterano de Palmas, Palmas, 2015.

7. Lindenmeyer LP, Goulart VP, Hegele V. Reconciliação medicamentosa como estratégia para a segurança do paciente oncológico- resultados de um estudo piloto. Rev. Bras. Farm. Hosp. e Serv. Saúde. 2013;3(4):51-55.

8. Institute for Healthcare Improvement. How-to guide: prevent adverse drug events (medication reconciliation). Disponível em: http://www.ihi.org/resources/Pages/Tools/HowtoGuidePreventAdverseDrugEvents.aspx. Acesso em: 21 de agosto de 2018.

9. Gleason KM, Groszek JM, Sullivan C, et al. Reconciliation of discrepancies in medication histories and admission orders of newly hospitalized patients. Am J Health-Syst Pharm. 2004;61(16):1689-1695.

10. Lessard S, Deyoung J, Vazzana N. Medication discrepancies affecting senior patients at hospital admission. Am J HealthSyst Pharm. 2006;63(8):740-3.

11. Vira T, Colquhoun M, Etchells E. Reconcilable differences: correcting medication errors at hospital admission and discharge. BMJ Quality \& Safet. 2006;15(2):122-126.

12. Ketchum K, Grass, CA, Padwojski A. Medication reconciliation: verifying medication orders and clarifying discrepancies should be standard practice. Am J Nurs. 2005;105(11):78-79, 81-82, 84-85.

13. Manzorro AG. Programa para la conciliación de la medicación al ingresso en una unidad de cirugía general [Dissertação de doutorado]. Faculdad de Farmacia de Granada, Granada, 2013.

14. Mendes AEM. reconciliação de medicamentos na admissão hospitalar: um ensaio clínico randomizado [Dissertação de Mestrado]. Universidade Federal do Paraná, Curitiba, 2016.

15. Silva $A E B C$, Reis AMM, Miasso Al, et al. Eventos adversos a medicamentos em um hospital sentinela do Estado de Goiás, Brasil. Rev. Latino-Am. Enfermagem. 2011;19(2):[Tela 1-Tela 9]

16. Silvestre CC. Necessidade da conciliação de medicamentos: avaliação da história da farmacoterapia de pacientes admitidos em um hospital universitário [Dissertação de mestrado]. Universidade Federal de Sergipe, São Cristóvão, 2014.

17. Alves M, Ramos FRS, Penna CMM. O trabalho interdisciplinar: aproximações possíveis na visão de enfermeiras de uma unidade de emergência. Texto Contexto Enferm. 2005;14(3):323-331.
18. Cano FG. Eventos adversos a medicamentos no ambiente hospitalar [Tese de doutorado]. Escola Nacional de Saúde Pública Sergio Arouca, Rio de Janeiro, 2011.

19. Melo A, Frade J. Serviços Farmacêuticos diretamente destinados ao paciente, à família e à comunidade - Contextualização e arcabouço conceitual. Brasília: Conselho Federal de Farmácia, 2016.

20. Conselho Federal de Farmácia. Serviços Farmacêuticos: Contextualização e arcabouço conceitual. Brasília: Conselho Federal de Farmácia, 2014.

21. Correr CJ, Otuki MF, Soler O. Assistência farmacêutica integrada ao processo de cuidado em saúde: gestão clínica do medicamento. Rev Pan-AmazSaude. 2011;2(3):41-49.

22. Correr CJ, Otuki MF, Soler O. Método Clínico de Atenção Farmacêutica. Disponível em: http://www.saude.sp.gov.br/resources/ipgg/assistencia-farmaceutica/otuki-metodoclinicoparaatencaofarmaceutica.pdf. Acesso em: 14 de setembro de 2018.

23. Filho NCA, Souza AMP. A percepção sobre o trabalho em equipe multiprofissional dos trabalhadores de um Centro de Atenção Psicossocial em Salvador, Bahia, Brasil. COMUNICAÇÃO SAÚDE EDUCAÇÃO. 2017; 21(60):63-76

24. NASCIMENTO, J.C; DRAGANOV, P.B. História da qualidade em segurança do paciente. Hist enferm Rev eletronica. 2015;6(2):299-309.

25. REBRAENSP. Estratégias para a segurança do paciente. Porto Alegre: EDIPUCRS, 2013.

26. RIGOBELLO, MCG, et.al. Clima de segurança do paciente: percepção dos profissionais de enfermagem. Acta paul. enferm., 2012; 25, 728-735.

27. SILVESTRE, CARINA; LYRA JUNIOR, DIVALDO . THE THREE CS OF MEDICINES RECONCILIATION: REALITY AND PERSPECTIVES. Revista Brasileira de Farmácia Hospitalar e Serviços de Saúde, v. 9, p. e091.001, 2018.

28. Rigobello MCG, Carvalho REFLD, Cassiani SHD, et al. Clima de segurança do paciente: percepção dos profissionais de enfermagem. Acta paul. enferm. 2012;25(5):728-735.

29. SILVESTRE, CC, et. al. Risk factors for unintentional medication discrepancies at hospital admission: A matched case-control study. European Journal of Internal Medicine JCR, v. 40, p. e24-e25, 2017.

30. Mekonnen AB, McLachlan AJ, Brien JA. Pharmacy-led medication reconciliation programmes at hospital transitions: a systematic review and meta-analysis. J Clin Pharm Ther. 2016 Apr;41(2):128-44.

31. Najafzadeh M, Schnipper JL, Shrank WH, Kymes S, Brennan TA, Choudhry NK. Economic value of pharmacist-led medication reconciliation for reducing medication errors after hospital discharge. Am J Manag Care. 2016 Oct;22(10):654-661

32. Elbeddini A, Almasalkhi S, Prabaharan T, Tran C, Gazarin M, Elshahawi A. Avoiding a Med-Wreck: a structured medication reconciliation framework and standardized auditing tool utilized to optimize patient safety and reallocate hospital resources. J Pharm Policy Pract. 2021 Jan 19;14(1):10 
